DOI: https://doi.org/10.32839/2304-5809/2021-4-92-38

УДК 378.018.43:004]:[613.6:617.75]

Братусь I.B. ${ }^{1}$

Київський університет імені Бориса Грінченка

Свердлик 3.M.2

Київський національний університет культури і мистецтв

Гунька A.M. ${ }^{3}$

Київський університет імені Бориса Грінченка

\title{
ЗНИЖЕННЯ ВТОМИ ОЧЕЙ ПРИ РОБОТІ В РЕЖИМІ ДИСТАНЦІЙНОГО ТА КОМБІНОВАНОГО НАВЧАННЯ
}

Анотація. У статті наводяться шляхи оптимізації навантаження на очі при роботі з пристроями під час дистанщійного навчання. Стаття містить узагальнюючий досвід використання різних типів обладнання. Основна увага надається зменшенню напруження очей шляхом правильно встановлених параметрів обладнання монітору та відеоадаптеру. Ці вказівки добираються індивідуально у відповідності до специфріки сприйняття людини. Особливу увагу варто звернути на кольорову температуру, на відтінки сірого та частоту оновлення. При цьому важливо враховувати роздільну здатність дисплею. Окремо розглядаються пристрої на базі Андроїд - додано пояснювальні скріншоти окремих параметрів, що можуть полегшити тривалу роботу з гаджетами. Ключові слова: екран, очі, дистанційне навчання, мерехкотіння, втома, COVID-19.

\author{
Bratus Ivan \\ Borys Grinchenko Kyiv University \\ Sverdlyk Zoriana \\ Kyiv National University of Culture and Arts \\ Gunka Anna \\ Borys Grinchenko Kyiv University
}

\section{REDUCING EYE FATIGUE (DISTANCE LEARNING)}

Summary. The article presents ways to optimize eye strain when working with devices in distance learning. The article contains generalized experience of using different types of equipment. The main focus is on reducing eye strain through properly set equipment parameters - monitor and video adapter. These instructions are selected individually in accordance with the specifics of human perception. Particular attention should be paid to color temperature, shades of gray and refresh rate. It is important to consider the resolution of the display. Android-based devices are considered separately - explanatory screenshots of certain parameters are added, which can facilitate long-term work with gadgets. Various devices are used for distance learning. These are mostly desktop computers with monitors, tablets, smartphones or laptops. In 2019, the pandemic took over the world at a rapid pace and many people used "what was there" to implement the educational process, some had to make a "quick investment" for technical re-equipment. At the same time, even powerful educational institutions left their teachers and students to solve the problem on their own - computers, projectors and multimedia boards were left in empty classrooms. At the same time, the "digital advance" of the institution was not superfluous - corporate mail and the establishment of a distance learning system helped to ease the transition to remote communication. The pandemic clearly demonstrated the difference between knowledgeable, simulated and hopelessly backward users due to various circumstances. Those who had a low level of awareness and expressed a desire were able to make up for the gap in a short time. But due to the long stay in front of the screens, health problems, including vision, did not linger. When working with the screen it is necessary to take into account the external lighting. It is worth noting here that it is not just the ambient light that is crucial, but the contrast between the brightness of the screen and the ambient light. This contrast is that a bright screen in a completely darkened room is much more "pressing" on the eyes than in a well-lit room. The use of gadgets for distance learning also has the advantage that participants in the educational process can engage in moderate physical activity during classes. Of course, this format is acceptable only if concentration is maintained.

Keywords: screen, eyes, distance learning, flicker, fatigue, COVID-19.

Постановка проблеми. В сучасній освіті 1 вже неможливо уникнути використання IКT. Ми постали перед викликами XXI століття весь світ прагне діджіталізації. Вона визначає рівень конкурентоспроможності та формуе «нову реальність». Поряд 3 перевагами нового рівня інформатизації постають і нові виклики, що супроводжують прогрес. Це й психологічна залежність від гаджетів, і фрізичні небезпеки. Всі ці проблеми досліджуються за мірою їх появи. Деким вченим вдається їх передбачити наперед i попередити освітянську спільноту. Але варто визнати - динаміка змін настільки стрімка, що важко втілювати в життя дієві рішення протидії негативному впливу деяких фракторів діджіталізації.

Одним з цих фракторів $є$ шкода для очей. Усталені методики оцінки норм роботи з комп'ютерною технікою застарівають. Особливо збільшилося навантаження на очі під час пандемії COVID-19. Це було викликано потребою майже постійно знаходитися «перед екраном». Відповідно до цих обставин освітяни здійснили спроби покращити 
своє апаратне та програмне забезпечення. Для України подібні придбання часто пов'язані з значними матеріальними витратами (неспіввідносними 3 доходом). Відповідно особливо актуальною стала оптимізація наявного обладнання у відповідності до збільшеного навантаження на очі. Цьому й присвячене наше дослідження.

Аналіз останніх досліджень і публікацій. Проблема збереження зору при роботі 3 дисплеями вже тривалий час турбуе дослідників. Так 3. Мартинова [2] в своїй статті дослідила широкий спектр впливу різноманітних фракторів, що виникають при роботі на комп'ютері, на здоров'я учнів. В їі розвідщі наявна інформація про правильну посадку за комп'ютером, освітлення та багато іншого. Теоретичний матеріал в роботі дослідниці поєднаний $з$ даними анкетування.

3 медичної точки зору вплив комп'ютерної техніки на здоров'я людини описано в статті Н. Дрожжиної, А. Фоминої та I. Михайлова [1]. В цій публікації концептуально зібрані відомості про задану тематику з широким спектром статистичних відомостей.

Безпосередньо зорове навантаження педагогів подано в роботі Г. Кригер [3]. В щій публікації наявні важливі спостереження та слушні поради. Матеріал досліджено на базі роботи в коледжі. Але він може бути корисним для середньої та вищої школи.

Виділення не вирішених раніше частин загальної проблеми. В дослідженні представлена комбінація кроків покрашення роботи 3 дисплеями різноманітних пристроїв.

Мета статті. В статті ми пропонуемо шляхи зменшення напруження очей під час дистанційного навчання.

Виклад основного матеріалу. Для дистанційного навчання використовуються різноманітні пристрої. Здебільшого це стаціонарні комп'ютери з монітором, планшети, смартфони чи ноутбуки. В 2019 році пандемія COVID-19 захопила світ швидкими темпами і для впровадження освітнього процесу багато хто використовував «що було», декому довелося робити «швидку інвестицію» задля технічного переобладнання. Прикро, що більшість подібних кроків відбувалися «хаотично». При џому навіть потужні освітні установи здебільшого залишили своїх педагогів і учнів/студентів вирішувати проблему самотужки - комп'ютери, проектори та мультимедійні дошки лишилися в порожніх аудиторіях. При цьому «цифрова просунутись» установи не була зайвою - корпоративна пошта та налагодженні системи дистанційного навчання допомогли пом'якшити перехід до віддаленого спілкування. Пандемія наочно продемонструвала відмінність між обізнаними, «імітаторами» та безнадійно відсталими в силу різних обставин користувачами. Та навіть ті, хто мав низький рівень обізнаності та виявив бажання засвоїти IКТ, зуміли здебільшого в короткий час надолужити відрив від сучасності (мотивом було й розуміння довготривалості локдауна). Та внаслідок тривалого перебування перед екранами не забарилися й проблеми 3 здоров'ям, зокрема 3 зором.

В Біблії око назване світильником тіла (Свангелія від Матвія 6:22). Безумовно, що тут мається на увазі передусім духовна складова, але й фрізичне світло також має велике значення. Саме світло й колір дозволяють нам бачити «яскравий світ».
Та одночасно вони стають фракторами подразнення наших очей, викликають відчуття дискомдрорту. Тобто у витоці проблем 3 очима виступають джерела світла. Розглянемо основні фрактори, що негативно впливають на наше сприйняття.

При роботі з екраном необхідно враховувати зовнішне освітлення. Тут варто зазначити, що вирішальну роль грає не тільки/скільки саме інтенсивне зовнішне освітлення, а контраст між яскравістю екрана та оточуючим світлом. Цей контраст полягає в тому, що яскравий екран в повністю затемненому приміщенні значно сильніше «тисне» на очі, ніж в добре освітленому. Тому уникайте працювати в темному приміщенні - намагайтеся забезпечити себе комфортним освітленням. При поганому освітленні варто зменшувати яскравість дисплею. В найбільш «просунутих» пристроях вбудований сенсор світла і є можливість використовувати інтелектуальну «автояскравість».

Спільною проблемою для екранів пристроїв та ламп освітлення є мерехкотіння. Ця проблема існувала ще за часів трубчатих моніторів. Для комфортної роботи необхідно дотримуватися не менше 60 герц. Цей параметр можна виставити/перевірити через «Панель керування» у пристроях на базі операційної системи Windows (рис. 1). Деякі сучасні монітори підтримують значно вищу частоту оновлення - 85, 100, 144 та навіть більше. Варто зауважити, що подібні значення більше орієнтовані на ринок ігрових рішень - висока частота необхідна для якісного геймплею. Ці рішення часто реалізуються з урізанням інших технічних характеристик, зокрема використовуеться матриця ТFT а не більш якісна ISP. До того ж підтримка 144 і вище вимагає наявності інтерфейсу Дісплей-порт та потужного відеоадаптеру. Ці нюанси мають бути враховані для використання комп'ютера для дистанџійного навчання - знання специфрікацій допомагає обрати більш відповідні апаратні рішення.

При виборі монітору для зменшення напруги на очі велике значення мають його роздільна здатність, величина пікселя та тип матриці. Для сучасних моніторів використовуються різні технічні рішення, що носять універсальний характер. Але окремі показники розроблені для рішення певних задач - відповідно вони мають значення для цих функцій. Роздільна здатність монітору відповідає за чіткість зображення. Особливо це важливо для роботи з текстом - літери при роздільній здатності 1920 на 1080 набагато краще сприймаються очима ніж при показнику 1024 на 798. Це легко побачити на прикладі літери «О» - при низькій роздільній здатності в їі контурі видно «перепади контуру».

Роздільна здатність корелюеться при цьому 3 діагоналлю монітору - чим вона вища, тим більшим є піксель. Великі пікселі погіршують зображення, підвищують втому очей. Так при роздільній здатності 1920 на 1080 і діагоналі 20" піксель буде 0,23 мм, а при діагоналі 32" при тій же роздільній здатності - 0,368 мм. Тобто щоб досягти прийнятних величин розміру пікселя необхідно при діагоналі 32" дотримуватись роздільної здатності 2560 на 1600. Має сенс при цьому тільки рекомендована виробником величина роздільної здатності, закладена технологічно (рис. 2), оскільки при нижчих і вищих показниках монітор працюе в режимі інтерполяції - цей 


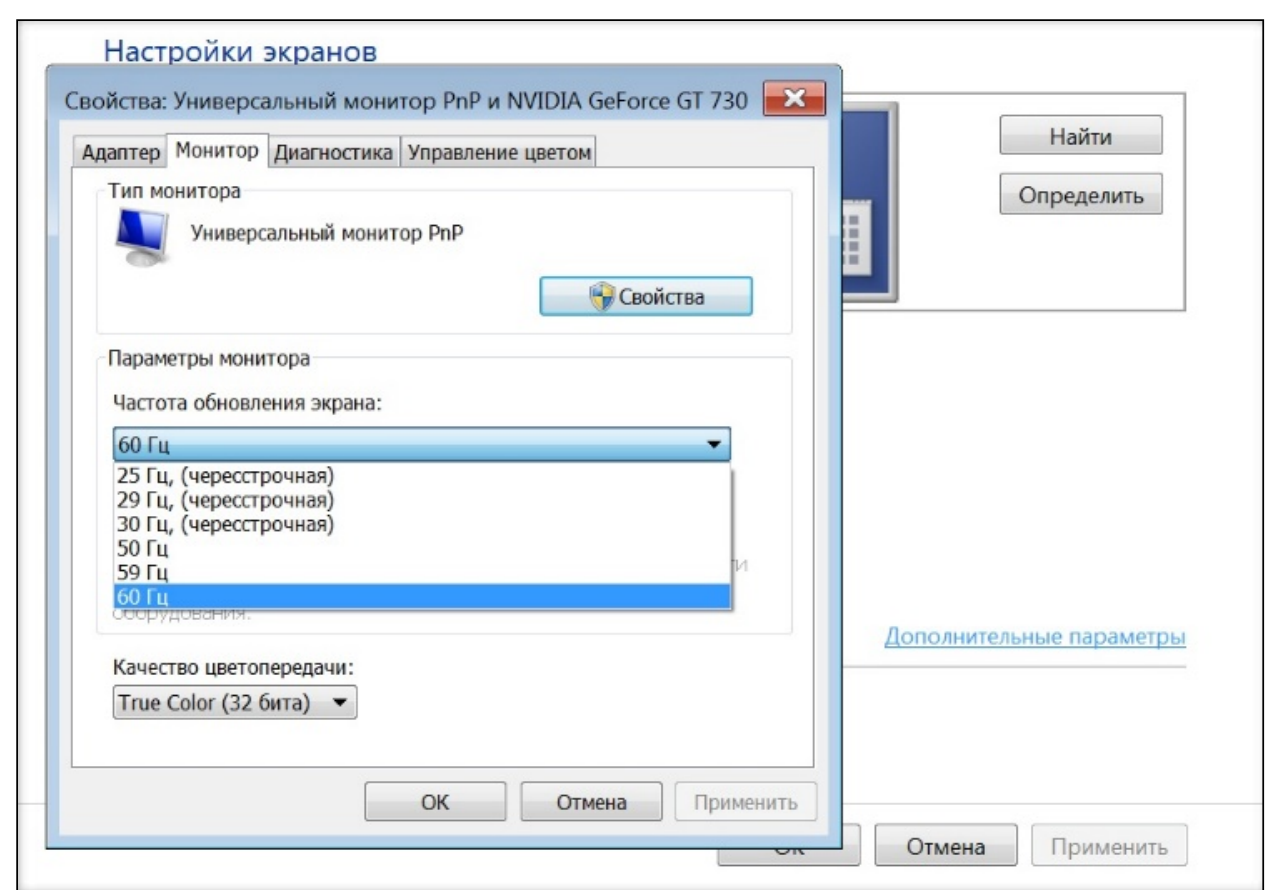

Рис. 1. Параметри частоти оновлення

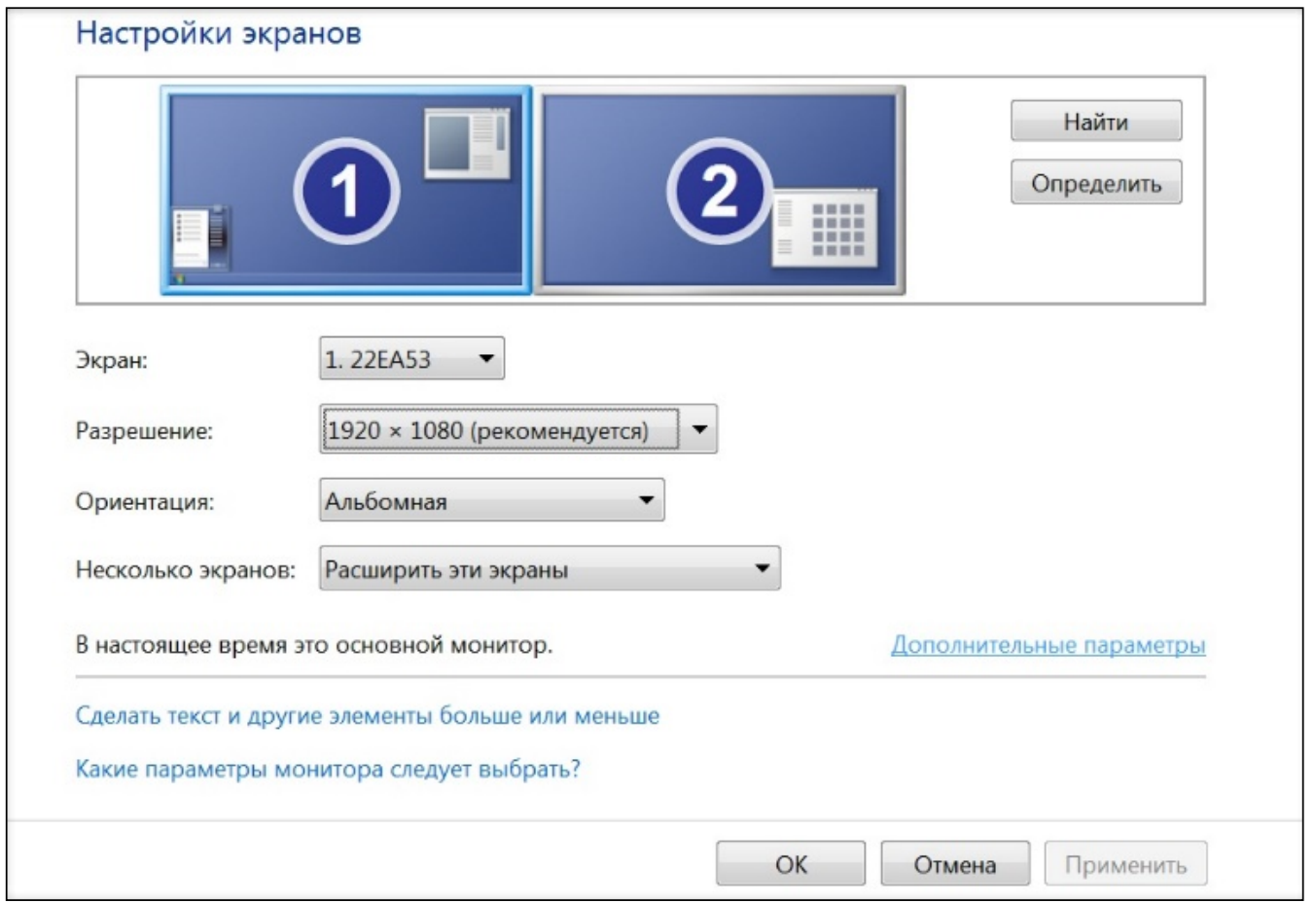

Рис. 2. Роздільна здатність екрану

режим не забезпечуе якості. Для сучасних моніторів (на відміну від минулих трубчастих) існуе тільки одна «рідна" роздільна здатність - вона зазначається виробником (це робота монітору в режимі «піксель в піксель»).

При високій роздільній здатності і невеликої діагоналі може задаватися, що зображення занадто «дрібне». Для џього у Windows існують інструменти масштабування (рис. 3) - ці програмні рішення допомагають більш відповідно підібрати прийнятний розмір тексту та елементів на екрані. Вони працюють без інтерполящї роздільної здатності, що дозволяє зберегти апаратні характеристики на високому рівні. Варто зауважити, що при дистанщійному на- вчанні в різних системах часто використовуеться багато дрібних елементів і механічне збільшення тексту може призвести до хаотичного їх розташування. Для більш точного налаштування можна використовувати програмні рішення самого браузера (наприклад, збілышення тексту затисканням лівої клавіши «Ctrl» і натисканням клавіши «+», а зменшення - затисканням лівої клавіши «Ctrl» і натисканням клавіши «-» ; чи затисканням лівої клавіши «Ctrl» і коліщатка мишки (при наявності)).

Велике значення для здоров'я очей має «температура кольору». Краще використовувати «теплу» кольорову гаму - вона найбільш ближча до природного сонячного світла. «Жовтуватий» 


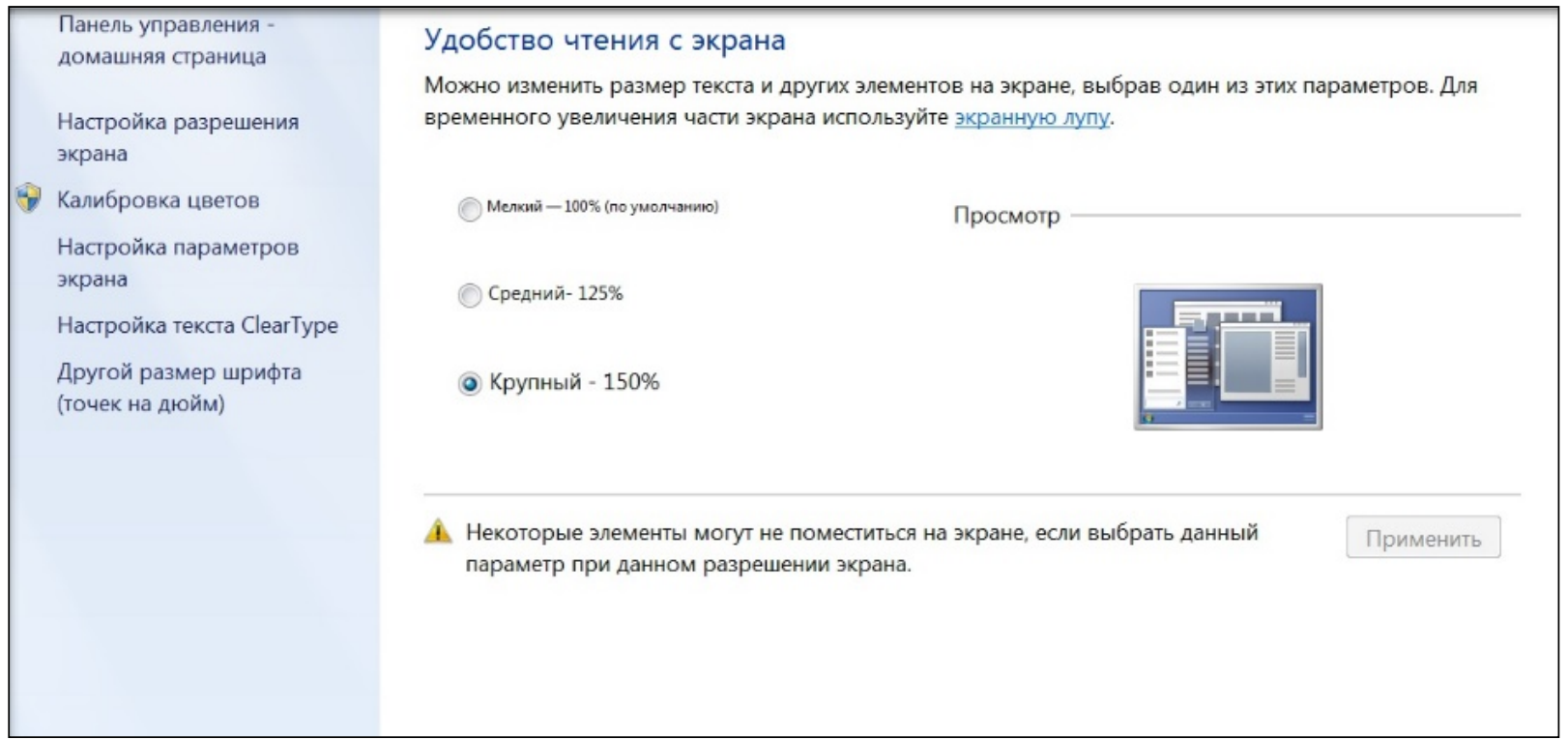

Рис. 3. Масштабування розміру текстів та інших елементів на екрані (Windows)

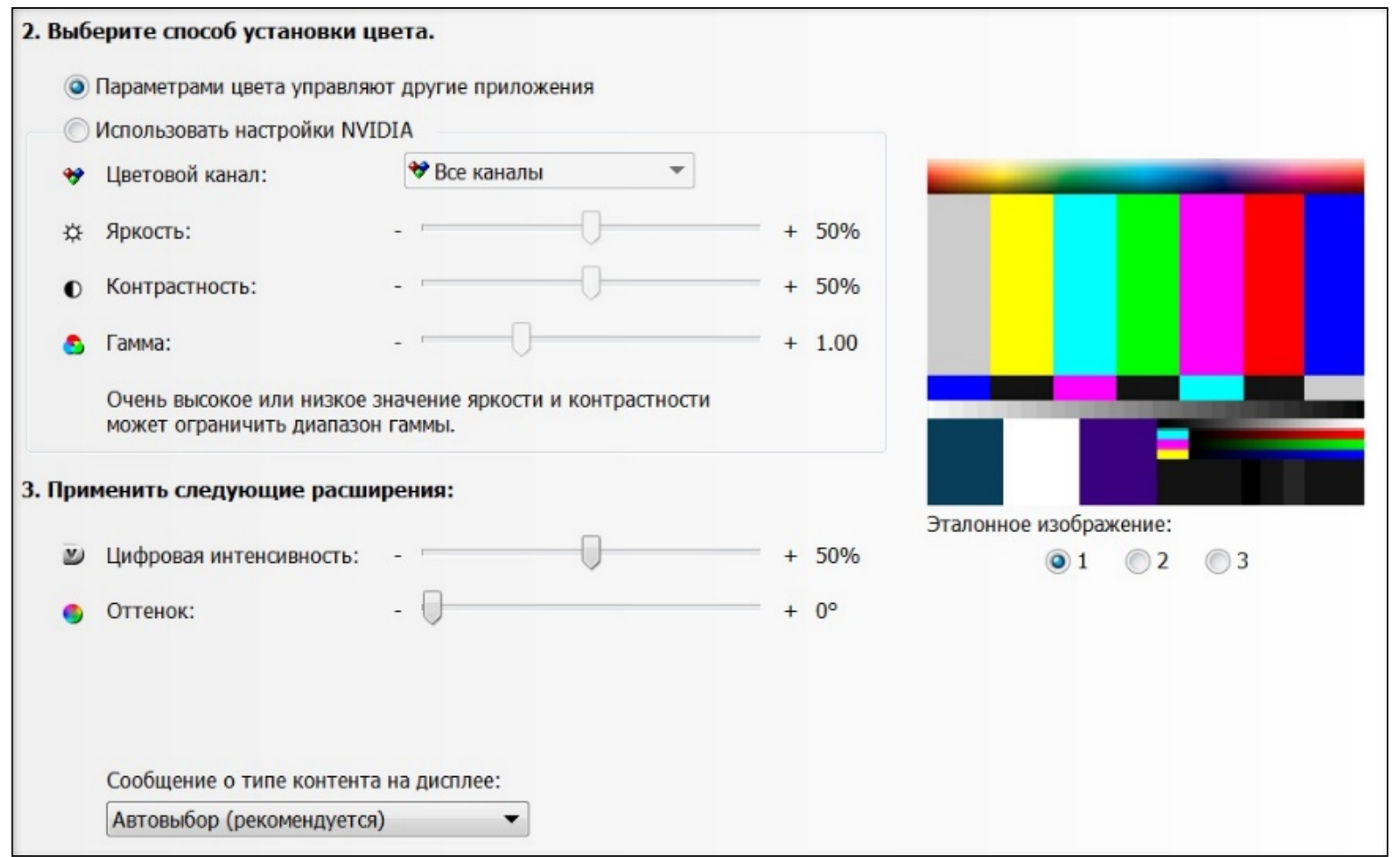

Рис. 4. Стандартні рівні керування кольору (Windows)

відтінок як правило встановлюеться в налаштуваннях монітору чи гаджету. В моніторах цей пункт налаштовуеться безпосередньо клавішами в самому пристрої - цей параметр може бути винесено окремо чи може бути представленим пакетним режимом, наприклад, «режим читання».

Більш «радикальним» $є$ шлях використання пристроїв у чорно-білому режимі. Подібний режим як правило підходить для текстових масивів (де некритичний колір). В системі Windows цей режим встановлюеться в параметрах налаштування відеоадаптеру, що мають відмінність в залежності від виробника відеокарти.

Розглянемо налаштування на прикладі відеоадаптеру NVIDIA. Для досягнення монохромного режиму необхідно перейти в налаштуван- ня відеоадаптеру - ці можливості передбаченні в драйверах NVIDIA, що встановлюються у відповідності до моделі пристрою (рис. 4).

В меню налаштування відеоадаптеру треба знизити до мінімуму «цифрову інтенсивність» та «відтінок» (рис. 5). В разі потреби повернення «кольорового режиму» процедуру необхідно повторити у зворотному порядку. Окремо варто звернути увагу на яскравість - їі високий рівень призводить до значної втому очей. Одночасно на деяких моделях моніторів зниження яскравості нижче 100\% призводить до мерехкотіння. Тому важливо в таких випадках яскравість зменшувати програмно (через драйвер відеоадаптеру), а не апаратно (через кнопки монітору). В деяких сучасних моделях моніторів зниження яскравос- 


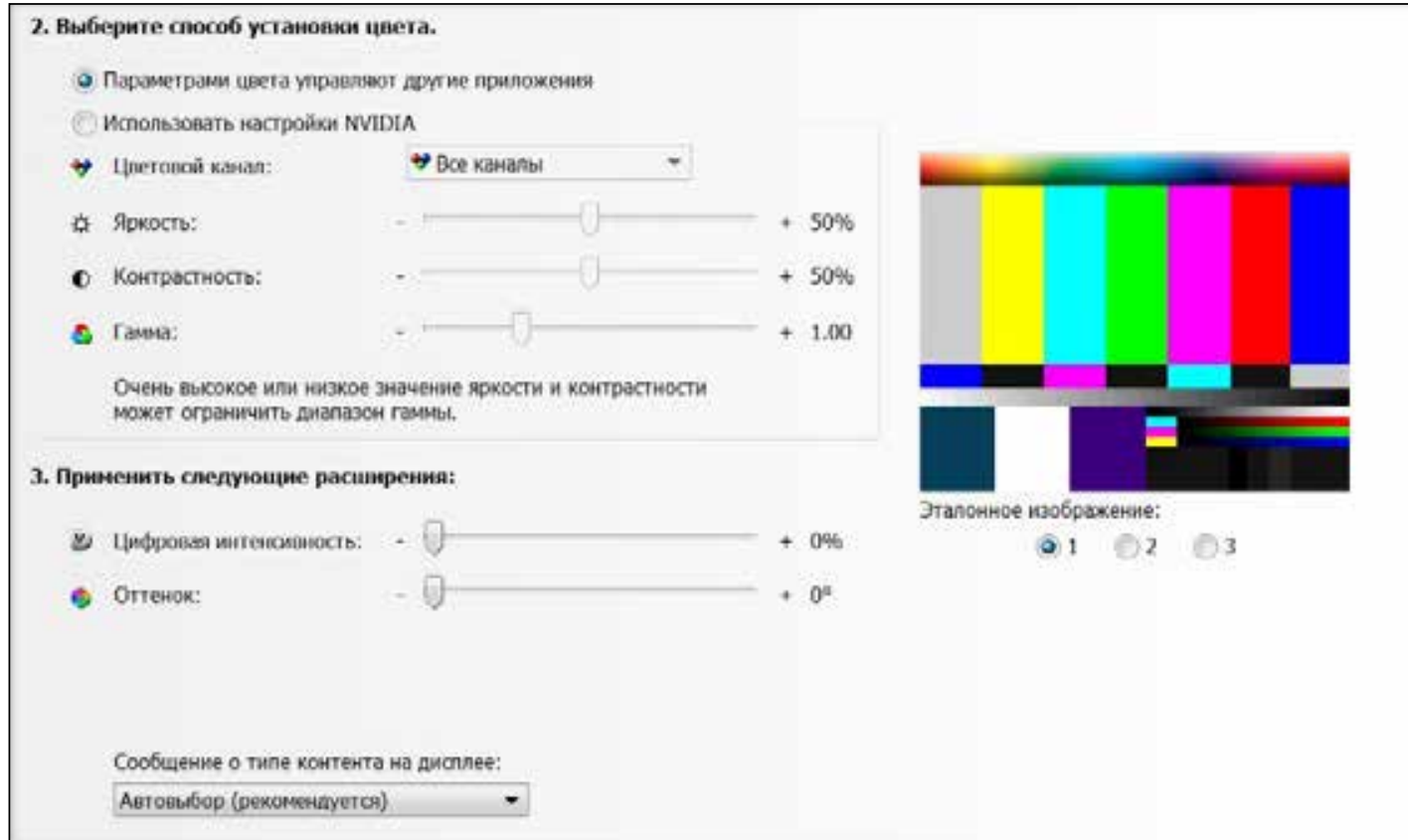

Рис. 5. Монохромний режим керування кольору (Windows)

ті апаратно не призводить до мерехкотіння - це досягається за допомогою технології Flicker-Free. При купівлі нового монітору для дистанційного навчання варто звернути на це пильну увагу.

Для пристроїв на базі Андроїд монохромний режим має різні алгоритми включення в залежності від версії операційної системи. В версіях до десятої версії цей режим включається в розширеному «режимі розробника» (цей режим підключають в різний спосіб в залежності від моделі телефону/планшету, як правило багаторазовим натисканням на пункті «номер збірки» в налаштуваннях) (рис. 6).

Для пристроїв на базі Андроїд до десятої версії в цьму режимі необхідно обрати режим «Монохроматизм» в пункті «Імітувати аномалію» (рис. 7). При потребі повернення «кольорового режиму» процедуру необхідно повторити у зворотному порядку.
В десятій версії Андроїду (та більш вищих) монохромний режим включаеться в налаштуваннях через пункт «Цифрове благополуччя і батьківський контроль» (рис. 8).

В пункті «Цифрове благополуччя і батьківський контроль» $є$ можливість точно за часом включати «Нічний режим». При цьому необхідно обрати підпункт «Відтінки сірого». Відповідно екран гаджету стає чорно-білим, що може значно знизити напругу очей (рис. 9).

Для зменшення напруження на очі під час дистанщійного навчання необхідно також зменшити рівень яскравості до прийнятних величин (при џьому звертається увага на наявність мерехкотіння, що може з'являтися при зниженні яскравості) (рис. 10). Мерехкотіння можна перевірити за допомогою цифрового фротоапарату чи іншого

Додатково
Надання та відкликання
дозволів
Сенсорний помічник
Ярлики жестів та кнопок
Індикація
Навушники та звукові
ефекти
Керування однією рукою
Спеціальні можливості
Для розробників
Відновлення та скидання
Мі Мокег

Рис. 6. Режим

"Для розробників" (Андроїд)

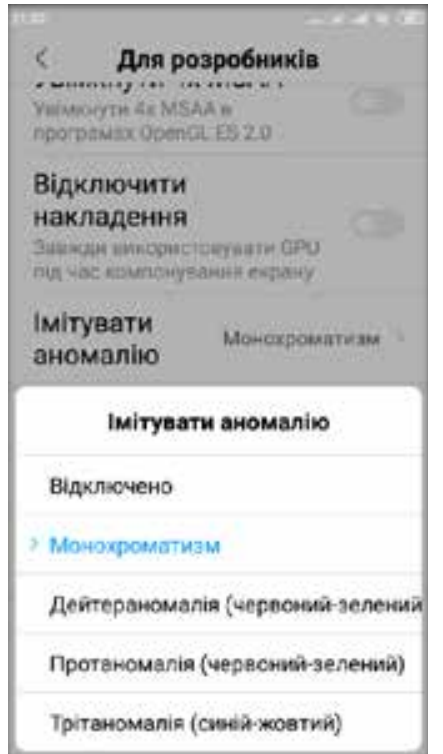

Рис. 7. Масштабування розміру текстів та інших елементів на екрані (Андроїд)

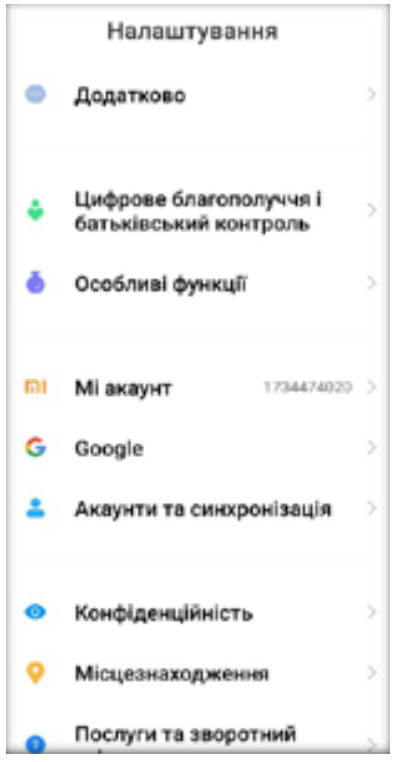

Рис. 8. Пункт «Цифрове благополуччя і батьківський контроль" (Андроїд) 


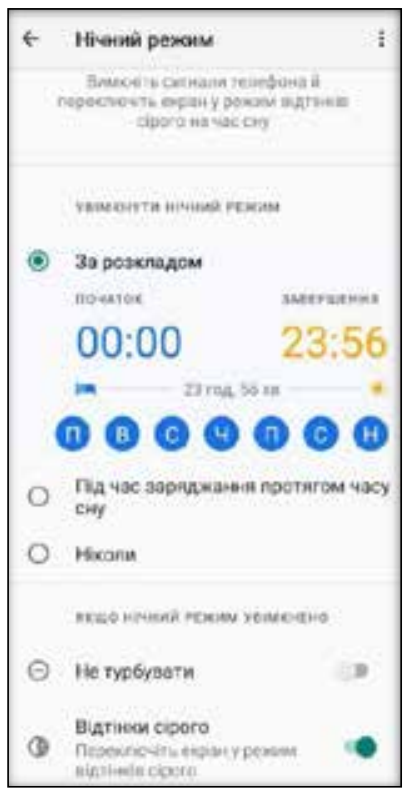

Рис. 9. Пункт «Цифрове благополуччя і батьківський контроль» - нічний режим і відтінок сірого (Андроїд)

телефона/планшета 3 камерою - в режимі зйомки подивитися на включений екран (в разі мерехкотіння воно буде видне на другому екрані). Також радимо включити «Режим читання» - він робить зображення більш «жовтішим» (рис. 10). Необхідно також звернути увагу на розмір шрифтів - рекомендуємо поставити не менше L (рис. 10).

Використання гаджетів для дистанційного навчання має й ті переваги, що учасники освітнього процесу можуть займатися помірними фрізичними вправами під час занять. Безумовно, що цей формат припустимий лише за умов дотримання відповідної концентрації уваги.

Висновки і пропозиції. Ми лише коротко оглянули можливості зменшення втоми очей при роботі з дистанційним навчанням. Адаптація до роботи в умовах пандемії для учнів і педагогічних працівників повинна проходити у відповідності до новітніх відомостей про шкоду тривалого перебування перед екранами. Новий етап еволюції інформаційно-комунікативних технологій

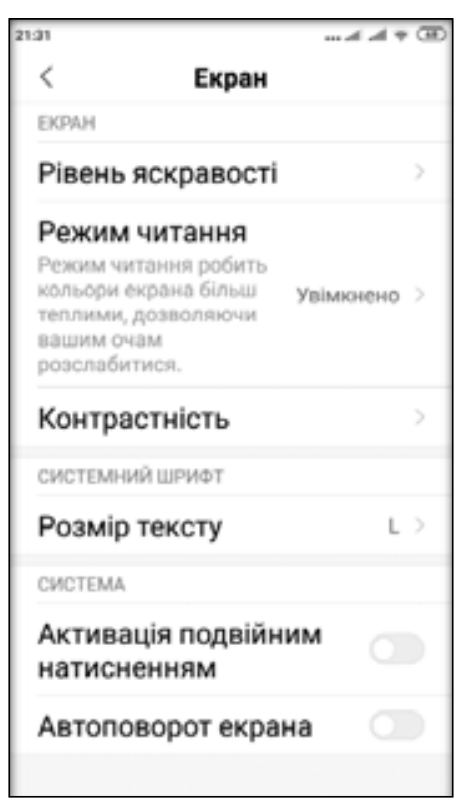

Рис. 10. Масштабування розміру текстів та інших елементів на екрані (Андроїд)

\section{Список літератури:}

1. Дрожжина Н.А., Фомина А.В., Михайлов И.М. Оценка влияния на здоровье человека различных факторов, возникающих при работе на компьютере. Вестник Российского университета дружбы народов. Серия : Медицина. 2003. № 5. С. 57-60.

2. Мартынова 3.Е. Влияние компьютера на жизнь и здоровье учащихся. Crede Experto: mpaнсnорт, общество, образование, язык. 2014. № 2. С. 212-221.

3. Кригер Г.С. Анализ зрительной нагрузки и выраженности симптомов зрительного утомления педагогов в образовательном процессе колледжа. История и педагогика естествознания. 2016. № 1. С. 26-28.

\section{References:}

1. Drozhzhina N.A., Fomina A.V., Mikhaylov I.M. (2003). Otsenka vliyaniya na zdorov'ye cheloveka razlichnykh faktorov, voznikayushchikh pri rabote na komp'yutere [Assessment of the impact on human health of various factors that arise when working on a computer]. Vestnik Rossiyskogo universiteta druzhby narodov. Seriya: Meditsina [Bulletin of the Peoples' Friendship University of Russia. Series: Medicine], 5, 57-60. (in Russian)

2. Martynova Z.Y. (2014). Vliyaniye komp'yutera na zhizn' i zdorov'ye uchashchikhsya [Influence of the computer on the life and health of students]. Crede Experto: transport, obshchestvo, obrazovaniye, yazyk [Crede Experto: transport, society, education, language], 2, 212-221. (in Russian)

3. Kriger G.S. (2016). Analiz zritel'noy nagruzki i vyrazhennosti simptomov zritel'nogo utomleniya pedagogov v obrazovatel'nom protsesse kolledzha [Analysis of the visual load and the severity of symptoms of visual fatigue of teachers in the educational process of the college]. Istoriya i pedagogika yestestvoznaniya [History and Pedagogy of Natural Science], 1, 26-28. (in Russian) 